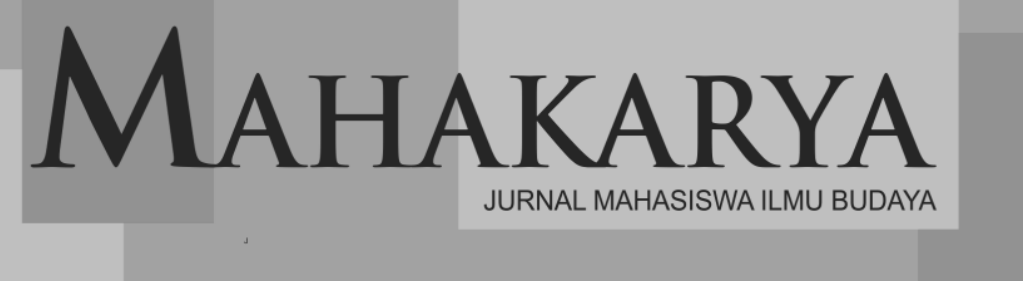

E-ISSN: 2798-0960 P-ISSN: 2798-0987

Volume 2 Nomor 1 - Juni 2021

\title{
PENGGUNAAN STRATEGI KETIDAKSANTUNAN JULUKAN TAK PANTAS DALAM SINIAR DEDDY CORBUZIER
}

\author{
Anisah Hanif \\ anisahhanif4@gmail.com \\ Program Studi Magister Ilmu Linguistik \\ Universitas Sebelas Maret \\ Surakarta
}

\begin{abstract}
This research focused on the varieties of the use of improper nicknames as manifestations of impoliteness in using languages. The identification was based on the linguistic markers traced from the origins of the words used as the nicknames for the speech partners. Apart fro that, the identification was also emphasized on the purpose of using nicknames in speech acts. By applying qualitative-descriptive approach, the data of ths research are five oral conversations between the host and the guest taken from the podcast hosted by Deddy Corbuzier and broadcasted on YouTube. For collecting the data, the researcher combined two techniques based on linguistic and pragmatic perspective. Menawhile, for analyzing the data, pragmatic contextual analysis was applied. The findings showed that the use of improper nicknames can be distinguished into two, namely linguistic markers and the purpose of use. Some variants found are improper names by analogy, animal names, and disgusting objects, and negative facts.
\end{abstract}

Key words: impoliteness, strategy, linguistic markers, nickname, podcast

\section{PENDAHULUAN}

Saat ini banyak bermunculan fenomena bahasa berupa ketidaksantunan berbahasa. Penutur ketidaksantunan sering tidak menyadari bahwa ia tidak santun dalam bertutur. Jika hal ini dilakukan secara terus menerusoleh masyarakat Indonesia, ketidaksantunan berbahasa akan menjadi sesuatu hal yang lumrah dan mengarah pada kebiasaan. Menurut Culpeper, ketidaksantunan berbahasa ditunjukkan melalui penggunaan bahasa yang menyerang atau menghilangkan muka (faceloss) mitra tuturnya (1996, 25). Padahal, dalam berkomunikasi, hubungan kerja sama antara penutur dan mitra tutur untuk saling menjaga muka sangat berpengaruh pada pesan yang akan disampaikan. Brown \& Levinson $(1987,61)$ menyatakan bahwa muka merupakan self-image atau citra diri yang dimiliki setiap individu. Dalam berkomunikasi, pihak-pihak yang terlibat harus saling menghargai dan menghormati sehingga komunikasi dapat berjalan dengan lancar, tanpa adanya serangan muka.

Culpeper $(2008,36)$ mengemukakan bahwa ketidaksantunan merupakan perilaku komunikasi dengan niat menyerang muka target (mitra tutur) atau menyebabkan target (mitra tutur) menjadi merasa demikian. Maksud definisi ini adalah bahwa tindakan ketidaksantunan bergantung pada niat penutur, pemahaman mitra tutur, dan hubungan di antara keduanya. Dengan kata lain, suatu tindakan mungkin dapat dikualifikasikan sebagai tindakan tidak santun apabila mitra tutur telah menganggap bahwa penutur merusak atau menghilangkan muka mitra tutur dan menampakkan tindakan mengancam. Masalah ketidaksantunan ini merupakan salah satu bidang kajian ilmu pragmatik.

Huang $(2017,2)$ mendefinisikan pragmatik sebagai salah satu ilmu yang paling marak dan cepat perkembangannya di bidang linguistik dan filsafat bahasa. Pada masa sekarang ini, pragmatik terus menjadi topik utama dalam ilmu pengetauan kognitif, kecerdasan buatan, informatika, neurosains, antropologi, sosiologi, dan patologi bahasa. 
Huang juga menggaris bawahi bahwa pragmatik adalah pengkajian bahasa dengan konteksnya. Hal ini menunjukkan betapa pentingnya adanya konteks dalam kajian pragmatik.

Sementara itu, Leech $(1993,8)$ mendefinisikan pragmatik sebagai studi tentang makna dalam hubungannya dengan situsi-situasi ujar. Leech melihat pragmatik sebagai bidang kajian dalam linguistik yang mempunyai kaitan dengan semantik. Keterkaitan ini ia jabarkan dalam tiga istilah, yaitu semantisisme, pragmatisme, dan komplementarisme. Semantisisme melihat semantik sebagai bagian dari pragmatik. Sebaliknya, pragmatisisme, memandang pragmatik sebagai bagian dari semantik. Sementara komplementarisme menganggap semantik dan pragmatik sebagai dua bidang yang saling melengkapi. Lebih lanjut Leech menjelaskan bahwa kajian pragmatik terkait langsung dengan fungsi utama bahasa, yaitu sebagai alat komunikasi. Pengkajian pragmatik selalu terarah pada permasalahan pemakaian bahasa dalam suatu masyarakat bahasa untuk untuk mengungkap bagaimana perilaku berbahasa masyarakat tersebut dalam bersosialisasi

Di sisi lain, Mey $(1993,41)$ berpendapat bahwa pragmatik adalah pengkajian terhadap kondisi penggunaan bahasa oleh manusia yang dipengaruhi oleh konteks sosial. Jadi, kajian pragmatik melibatkan kondisi penggunaan bahasa dalam masyarakat. Penggunaan bahasa dalam masyarakat yang melibatkan penutur dan mitra tutur ini umumnya bersifat nyata dan alami.

Dalam pengkajian pragmatik, konteks merupakan hal yang sangat penting karena tanpa adanya konteks, tuturan hanyalah sebatas tuturan saja. Pentingnya konteks ini ditegaskan oleh Levinson (1997) yang menyatakan bahwa kajian pragmatik didasarkan pada kemampuan pengguna bahasa untuk menyesuaikan kalimat dengan konteks sehingga kalimat itu patut atau tepat diujarkan. Apabila pesan dapat tersampaikan dengan baik pada mitra tutur berarti komunikasi telah berjalan dengan lancar.

Nugroho (2009) juga berpendapat bahwa daya pragmatik (pragmatics force) sangat bergantung pada konteks yang berlangsung pada waktu tuturan diujarkan dalam sebuah peristiwa tutur. Tanpa melibatkan konteks, ujaran atau tuturan hanya dapat dilihat dari kata-kata saja. Padahal kajian pragmatik merupakan kajian yang berkaitan erat dengan konteks situasi tutur untuk mengetahui maksud dibalik tuturan yang diujarkan.

Sementara itu, Leech (1983) memerikan konteks sebagai salah satu komponen dalam situasi tutur. Menurut Leech, konteks didefinisikan sebagai aspek-aspek yang berkaitan dengan lingkungan fisik dan sosial sebuah tuturan. Leech menambahkan dalam definisinya tentang konteks, yaitu sebagai suatu pengetahuan latar belakang yang secara bersama dimiliki oleh penutur dan petutur. Konteks ini membantu petutur menafsirkan atau menginterpretasi maksud tuturan yang disampaikan penutur.

Studi tentang ketidaksantunan berbahasa telah menarik perhatian para peneliti dalam beberapa tahun terakhir. Ada beberapa studi tentang ketidaksantunan yang berfokus pada penggunaan strategi ketidaksantunan, yaitu Tasliati 2019, Suryanti 2019, Shinta 2018, Rinzat 2018, Wijayanto 2018, Wigati 2017, Mahbub 2017, dan Azma 2016. Penelitian-penelitian ini mengkaji penggunaan strategi ketidaksantunan pada berbagai sumber data. Hasil dari penelitian-penelitian ini, seluruhnya menunjukkan bahwa strategi ketidaksantunan yang paling dominan digunakan dan selalu muncul adalah strategi positif.

Dari berbagai penelitian yang telah dilakukan tersebut, peneliti menemukan celah penelitian (research gap) mengenai strategi ketidaksopanan positif, yaitu penggunaan julukan yang tidak pantas. Sejatinya, julukan digunakan sebagai media untuk mengakrabkan peserta tutur. Semakin akrab penutur dan mitra tutur, akan semakin luas dan bebas pula diksi julukan yang digunakan. Hal demikian ini terjadi, selain karena kedekatan jarak sosial, juga karena keduanya memiliki latar belakang pengetahuan yang sama. Sisi menarik yang dikaji dalam penelitian ini adalah penggunaan julukan tak pantas yang memicu timbulnya ketidaksantunan berbahasa. 
Berbagai penelitian mengenai ketidaksantunan berbahasa yang telah dilakukan sebelumnya sebagian besar di antaranya menggunakan media sosial seperti Instagram, grup Whatsapp, Facebook, dan Twitter sebagai sumber datanya. Sementara pada penelitian ini sumber datanya dari media sosial YouTube.

Fenomena ketidaksantunan berbahasa telah merambah ke mana-mana tanpa disadari dan bahkan cenderung tanpa batas. Hal ini membuat masyarakat terkontaminasi dengan penggunaan diksi atau bahasa dengan strategi ketidaksantunan. Padahal, dalam berkomunikasi, semua peserta harus berusaha untuk saling melindungi muka agar pesan bisa tersampaikan dengan baik. Strategi yang dilakukan oleh penutur ketidaksantunan pun seringkali tidak disadari oleh mitra tutur. Secara tidak langsung, mitra tutur tidak merasa bahwa ia telah terkena ancaman atau serangan muka. Penggunaan jenis strategi ketidaksantunan ini dapat direpresentasikan dengan strategi penggunaan julukan yang tidak pantas.

Dalam berkomunikasi, penutur sering menggunakan julukan sebagai pengganti nama atau panggilan mitra tuturnya. Semakin akrab penutur dan mitra tutur, julukan yang digunakan akan semakin bebas dan diksi yang digunakan juga semakin luas. Artikel ini akan menjelaskan mengenai penggunaan julukan dengan kata kasar atau tidak santun yang menyebabkan ketidaksantunan berbahasa. Karena pilihan kata yang digunakan dalam komunikasi sehari-hari sangat banyak dan beragam, penulis akan mengelompokkan diksi dan tujuan penggunaannya berdasarkan konteks peristiwa tutur.

Fenomena ketidaksantunan berbahasa ini, salah satunya dapat ditemukan pada penggunaan bahasa di internet. Salah satu platform media sosial yang saat ini paling banyak digunakan adalah YouTube. Melalui platform ini, berbagai aktivitas komunikasi dapat direkam dan diunggah secara bebas dan dapat diakses oleh seluruh pengguna internet. Pada masa sekarang ini, banyak artis televisi berbondong-bondong membuat channel YouTube dengan beraneka ragam konten. Akses ke YouTube ini cenderung tidak terbatas, sehingga dikhawatirkan akan semakin banyak tuturan yang mengandung ketidaksantunan dan dengan tujuan yang tidak benar akan mempengaruhi penggunaan bahasa masyarakat. Hal ini menarik untuk dikaji dari segi ketidaksantunan berbahasa karena jumlah channel YouTube sangat banyak dan penyebarannya juga sangat cepat.

Sumber data penelitian ini adalah lima rekaman video siniar (podcast) YouTube Deddy Corbuzier. Apabila dilihat dari sudut pandang linguistik, dari sumber data siniar ini ditemukan data yang cukup berlimpah mengenai fenomena ketidaksantunan berbahasa baik dalam ranah strategi penutur ketidaksantunan, respons mitra tutur terhadap ketidaksantunan berbahasa, dan alasan penggunaan ketidaksantunan berbahasa. Melalui penelitian ini akan diidentifikasi dan dieksplorasi pihak-pihak yang berperan terhadap keberadaan strategi, respons, maupun alasan penggunaan ketidaksantunan berbahasa yang muncul dalam siniar YouTube tersebut.

Menurut Fadhillah (2017) acara podcast atau siniar memiliki konsep yang sama dengan acara bincang-bincang atau talkshow di televisi. Dominasi media untuk penyelenggaraan acara semacam ini masih dipegang oleh televisi, baru kemudian disusul oleh internet. Baik acara siniar mapun bincang-bincang, keduanya sama-sama berisi wawancara mendalam dengan bintang tamu atau narasumber untuk membahas topik tertentu. Meskipun demikian, acara siniar di YouTube lebih alamiah dan bebas kepentingan daripada acara bincang-bincang di televisi. Halini karena acara bincangbincang di televisi seringkali harus melalui proses pemotongan dan penyuntingan, baik atas inisiatif pihak televisi sendiri maupun atas saran dan perintah lembaga sensor dan KPI (Komisi Penyiaran Indonesia) sebagai pengawas tayangan televisi.

\section{METODE PENELITIAN}

Kasper (2000:282) mengkategorikan pemerolehan data dalam penelitian pragmatik berasal dari tiga kategori; interaksi, kuisioner, dan laporan pribadi. Dalam kategori interaksi, jenis authentic discourse disegmantasikan menjadi dua; ordinary conversation dan interaksi institusional. Perbedaan antara keduanya, ordinary 
conversation berbentuk percakapan sehari-hari dan interaksi institusional berkaitan dengan percakapan yang terjadi dalam lembaga-lembaga tertentu.

Penelitian ini menggunakan metode kontekstual, cara-tujuan, padan pragmatis, dan metode heuristikuntuk tahapan menganalisis data yang telah ditemukan. Tahapan analisis data dalam penelitian ini menggunakan metode kontekstual. Metode konteksual adalah cara analisis yang ditetapkan pada data dengan mendasarkan, memperhitungkan, dan mengaitkan identitas konteks-konteks yang ada (Rahardi 2005, 16).

Selanjutnya, penelitian ini juga menggunaan metode padan pragmatis untuk menganalisis data yang telah ditemukan. Sudaryanto (1993, 14-15) mengatakan bahwa metode padan merupakan metode yang dipakai untuk mengkaji atau menentukan identitas satuan lingual tertentu dengan menggunakan alat penentu berupa mitra tutur. Metode ini biasa disebut dengan metode padan pragmatis. Penggunaan metode ini bertujuan untuk mengidentifikasi, misalnya satuan kebahasaan, menurut reaksi atau akibat yang terjadi atau timbul pada mitra tuturnya ketika satuan kebahasaan itu dituturkan oleh penutur kepada mitra tutur dalam situasi tertentu. Jadi, metode padan pragmatis dimanfaatkan untuk menganalisis wacana dari sudut pandang mitra tuturnya.

Data dalam penelitian ini merupakan data autentik yang berbentuk lisan atau percakapan antara pembawa acara siniar dengan bintang tamunya. Sumber data penelitian ini adalah lima rekaman video acara siniar Close the Door yang dipandu oleh Deddy Corbuzier dan disiarkan melalui kanal YouTube. Metode pemerolehan data yang digunakan dalam penelitian ini yaitu berupa dokumentasi percakapan asli dari rekaman video tersebut. Penggunaan rekaman video semacam ini cenderung lebih efektif kerena data yang diperoleh tidak hanya berupa suara atau audio saja, tetapi juga ada sisi visual atau gambarnya. Sisi visual ini sangat membantu peneliti dalam menafsirkan tuturan dan memperjelas interaksi dalam peristiwa tutur. Apabila hanya mengandalkan data audio saja, hasil analisis cenderung tidak lengkap karena peneliti tidak dapat mengetahui ekspresi penutur atau dengan kata lain pemerolehan data kurang komprehensif. Sementara dari sisi audio sendiri, peneliti juga dapat melibatkan intonasi dan nada dalam sebuah peristiwa tutur sebagai bagian dari unsur yang dianalisis.

\section{HASIL DAN PEMBAHASAN}

\section{Strategi Ketidaksantunan Positif dengan Julukan Tak Pantas}

Penggunaan julukan yang merepresentasikan strategi ketidaksantunan dalam berbahasa ini diidentifikasi berdasarkan kata yang dimaksud sebagai rujukan dan juga konteks peristiwa tuturnya. Julukan dengan kata yang tidak pantas ini berkaitan dengan penggunaan satuan lingual tertentu yang seharusnya tidak ada dalam konteks tuturan terkait. Satuan lingual ini dapat berupa kata atau frasa yang merepresentasikan anggota tubuh manusia atau pun berkaitan dengan unsur sosial dan budaya masyarakat tertentu. Berikut ini beberapa data yang merepresentasikan penggunaan julukan dengan kata-kata yang tidak pantas.

\section{Julukan dengan Nama Anggota Tubuh Manusia}

Salah satu variasi julukan tak pantas yang ditemukan dalam percakapan di siniar close the Door Deddy Corbuzier di YouTube adalah penyebutan anggota tubuh manusiayang ditujukan pada mitra tutur.

Data (1)

Konteks: Peristiwa tutur ini terjadi ketika Deddy Corbuzier (DC) sebagai pembawa acara menampilkan Uus (U) sebagai bintang tamunya. Keduanya berteman akrab sejak merintis kanal YouTube masing-masing pada waktu yang hampir bersamaan. Baik DC maupun U, kedua-duanya sama-sama sudah berumah tangga, meskipun yang pertama sudah berstatus sebagai orang tua tunggal. DC mengenal istri Us dengan baik sehingga ia juga mengetahui bahwa istri $U$ tersebut sering membagikan unggahan di media sosial dengan mengenakan pakaian yang tergolong seksi. Pada percakapan di bawah ini $U$ mengekspresikan kekesalannya dengan memberi julukan berupa nama anggota tubuh manusia kepada DC. 
U : Makanya gue bilang, elu nikahin cewek sesuai fetish elu, bangsat! Jadinya kalau misalkan ini kamu nggak usah mengharapkan konten itu dari orang lain, tapi dari istri loe sendiri juga bisa. Iya, kan?

DC : Bener.

U : Misalkan, Uus bukannya ngelarang istrinya tu joget-joget di Instagram. Bro, udah berapa perempuan yang kehilangan cita-citanya karena suaminya ngelarang.

DC : Suaminya melarang posting?

U : Kontol, Si Deddy, nih!

DC : Nanya baik-baik, malah marah-marah. Engga soalnya, tapi kan tetep aja saat bini loe posting itu mengganggu mata pria-pria.

U : Betul-betul.

Penutur ketidaksantunan pada Data (1) di atas adalah U yang menerapkan strategi ketidaksantunan positif melalui penggunaan julukan tak pantas ditujukan secara langsung kepada mitra tuturnya, DC. Penanda lingual ketidaksantunan ini dapat diidentifikasi dari tuturan U “Kontol, Si Deddy, nih!". Penggunaan d kata kontol sebagai sebutan atau julukan bagi mitra tutur ini dapat dikategorikan sebagai penghinaan dan merupakan sesuatu yang tidak pantas untuk dilakukan. Peristiwa ini terjadi karena awalnya DC tidak begitu memahami maksud tuturan U, sehingga ia bertanya untuk meminta penjelasan. Alih-alih memberikan penjelasan, U justru marah dan melontarkan kata tidak pantas tersebut kepada DC. Kata kontol dalam bahasa Jawa berarti alat kelamin laki-laki.

\section{Julukan dengan Perbandingan}

Bentuk lain penggunaan strategi ketidaksantunan berbahasa positif melalui penggunaan julukan tak pantas adalah dengan analogi atau perbandingan. Perbandingan ini dilakukan dengan menyamakan mitra tutur dengan objek lain yang memiliki kemiripan. Berikut ini data peristiwa tutur yang merepresentasikan penggunaan julukan tak pantas dengan cara membandingkan.

Data (2)

Peristiwa tutur ini melibatkan DC dan bintang tamunya, Ivan Gunawan (IG). Keduanya pernah dipertemukan dalam sebuah acara televisi bersama. Pada percakapan di bawah ini, IG memberikan julukan yang tidak pantas pada DC dengan membandingkan DC dengan sesuatu yang melekat pada dirinya, yaitu make up.

DC : $L u$ ya? $L u$ adalah orang pertama kali yang ngomong sama gue di TV. Di depan orang-orang nonton TV, ngomong: Ded, Shading loe ketebelan!

IG : Enggak. Loe juga kalau bikin shading hidung suka nggak tau diri, Ded!

DC : Tapi di TV loe ngomong.

IG : Mana?

DC : Ituh.

IG : Ya. Kenapa nggak diedit? Kan acara loe taping.

DC : Engga. Pada saat itu live.

IG : O ya. Maap. Oh, itu live?

DC : Iya.

IG : Loe sini sampe sini shading. Sini shading. Bedak ampe leher-leher. Loe kaya pengantin Jawa loe kalau bedakan!

DC : Anjing!

Pada peristiwa tutur di atas, terjadi ketidaksantunan berbahasa yang dilakukan oleh IG terhadap DC. IG sebagai penutur menggunakan strategi ketidaksantunan positif melalui penggunaan julukan tak pantas dengan cara membandingkan penampilan make up mitra tuturnya, DC, dengan istilah 'pengantin Jawa'. Kejadian ini bermula dari tuturan IG yang mengomentari make up/shading DC yang terlihat terlalu tebal. Kesalahan yang dilakukan IG adalah ia melontarkan ucapan tersebut dalam acara yang disirakan secara langsung (live) di televisi, sehingga tidak memungkinkan untuk dilakukan proses penyuntingan tayangan. IG menganalogikan riasan muka DC dalam 
acara tersebut dengan riasan pengantin Jawa dengan shading hidung tebal dan bedak yang dipakai hingga ke leher. Padahal, saat itu mereka sedang membawakan sebuah acara televisi yang tidak berkaitan dengan acara pernikahan. Perbandingan ini terdapat pada uaran Loe kaya penganten Jawa loe kalo bedakan! Penggunaan julukan dengan perbandingan ini umumnya ditandai dengan diksi kaya, seperti, bagai, sama dan sejenisnya. Julukan bagai penganten Jawa ini secara langsung merusak muka positif DC sebagai mitra tutur karena disampaikan dalam intonasi tinggi yang membuat orangorang di sekitar dan bahkan pemirsa televisi terkejut.

\section{Julukan dengan Nama Hewan}

Kasus lain penggunaan julukan tak pantas juga ditemukan dalam bentuk panggilan dengan nama hewan. Penyebutan nama hewan ini secara langsung akan merusak muka positif mitra tutur yang, tentu saja, tidak pantas untuk mendapatkan julukan tersebut. Meskipun demikian, julukan tak pantas dengan nama hewan ini lebih ditujukan sebagi olok-olok saja dan bukan dimaksudkan untuk menghina. Berikut ini contoh peristiwa tutur yang mewakili hal tersebut.

Data (3)

Peristiwa tutur ini melibatkan DC, sebagai pembawa acara, dan bintang tamunya, Onadio Leonardo (OL). Keduanya membicarakan mengenai sikap masyarakat Indonesia terhadap kasus video asusila mirip artis. Pada kesempatanini, OL berpendapat mengenai adanya beberapa kebijakan KPI yang menurutnya tidak masuk akal. Untuk mempertegas pendapatnya dan meyakinkan mitra tuturnya, OL menggunakan julukan tak pantas dalam ujarannya.

DC : Nafsu, normal. Tapi kalau loe udah melakukan cat calling. Trus, juga atau loe towel, there is become wrong. Action-nya kan yang jadi salah?

OL : Action-nya. Tapi kenapa Indonesia membesar-besarkan itu, ya? Sampai gajah aja tetek-nya di-blur.

DC : Taik loe, gajah tetek-nya di-blur?

OL : Demi Tuhan!

DC : Goblok, loe!

OL : Yaelahhh, sampai ke binatang, Nyet. Di-blur. Di-blur.

DC : Tetek gajah di-blur?

OL : Tetek gajah di-blur! Mau gue cari loe?

DC : Nggak ada. Nggak mungkin. Anjing!

Pada percakapan di atas, penggunaan julukan yang tidak pantas terdapat pada kata Nyet dari tuturan OL "Yaelahhh, sampai ke binatang, Nyet." Melalui ujaran ini, OL bermaksud meyakinkan DC mengenai adanya bagian tubuh hewan di televisi yang ikut disensor oleh KPI. Nyet di sini merupakan kependekan dari kata 'monyet' yaitu sejenis kera yang bulunya berwarna keabu-abuan dan berekor panjang. Sapaan ini menimbulkan ketidaksantunan berbahasa karena dapat merusak muka positif DC sebagai pembawa acara dalam siniarnya.

\section{Julukan dengan Sesuatu yang Menjïikkan}

Penggunaan julukan tak pantas lainnya dilakukan dengan menggunakan kata-kata yang merujuk pada sesuatu yang menjijikkan. Diksi semacam ini sama sekali tidak pantas diucapkan, apalagi digunakan untuk memanggil seseorang. Berikut peristiwa tutur yang di dalamnya ada penyebutan sesuatu yang menjijikkan.

Data (4)

Sama seperti data sebelumnya, peristiwa tutur ini juga melibatkan DC sebagai pembawa acara dan OL sebagai bintang tamu. Sebagai seorang suami, OL tidak pernah melarang cara berpakaian istrinya. Menurutnya, terjadinya kasus-kasus pelecehan seksual bukan karena kesalahan perempuan dalam berpakaian, tetapi murni kesalahan pelaku pelecehan seksual tersebut. Dalam upayanya untuk menyangkal pernyataan OL ini, DC melontarkan julukan tak pantas yang merujuk pada sesuatu yang menjijikkan. 
DC : Bukan kalau loe nggak suka ya harusnya loe sebagai suami menegur istri loe kalau salah atau berpakaiannya seperti itu.

OL : OK. Tapi karena gue sangat modern, gue modern banget, lho. I love budaya barat.

DC : Taik lah loe!

OL : Lah, kok gue taik? Gue suka banget budaya barat.

Pada peristiwa tutur di atas, strategi ketidaksantunan positif dalam bentuk penggunaan julukan tak pantas dilakukan DC melalui kata taik dalam ujarannya, "Taik lah loe!”. Ujaran ini dimaksudkan untuk merendahkan atau bahkan tidak mempercayai pendapat mitra tutur. Kata taik merujuk pada sesuatu yang menjijikkan sehingga tidak pantas diucapkan dan ditujukan pada mitra tutur. Istiah taik atau tai bersinonim dengan tinja yang berarti kotoran atau hasil buangan yang dikeluarkan dari bagian pencernaan makhluk hidup melalui lubang dubur.

\section{Julukan dengan Mengungkapkan Keadaan Mitra Tutur}

Varian terakhir julukan tak pantas dilakukan dengan cara mengungkapkan status atau keadaan mitra tutur. Pengungkapan keadaan semacam ini dapat menimbulkan ketidaksantunan berbahasa apabila memberikan kesan negatif pada mitra tutur. Hal ini disebabkan adanya konteks tertentu yang mengakibatkan pengungkapan keadaan yang sebenarnya tersebut justru menyerang muka positif mitra tutur. Untuk lebih jelasnya, berikut ini ditampilkan contoh penggunaan strategi tersebut.

Data (5)

Peristiwa tutur ini lagi-lagi melibatkan DC sebagai pembawa acara dan U sebagai bintang tamunya. Mula-mula U menyampaikan keluhan dan keresahan warga Twitter pada DC. Mereka menilai bahwa DC hanya memanfaatkan permasalahan yang terjadi melalui siniarnya. Apabila muncul suatu permasalahan yang ramai di masyarakat, pihak-pihak ang terlibat akan segera diundang ke acara siniar DC guna melakukan klarifikasi. Dari sini DC mendapatkan adsense atau iklan dari YouTube. Pada kesempatan ini, U telah menemukan celah untuk melakukan labelling pada DC dengan mengungkapkan kondisi kehidupan DC sesungguhnya, yaitu mengenai status pernikahannya.

DC : Saya bikin Kekeyi famous? Apa itu? Tasya Farasya? Apa orang-orang yang make up nyontohin dia? Kok, saya, sih? Dia udah famous, baru saya undang ke sini. Saya tidak membuat stupid people famous dan saya nggak menganggap Kekeyi stupid.

U : Eh, duda! Gini, ya. Aku kasih tau. Aku cuma menyampaikan apa yang ada di benak mereka. Gue pribadi, karena aku tau kalau mereka belum famous nggak akan diundang ke sini.

DC : Ya udah.

Pada peristiwa tutur di atas, strategi ketidaksantunan positif dengan memberi julukan tak pantas dilakukan $\mathrm{U}$ dengan mengungkapkan keadaan mitra tutur melalui ujaran "Eh, Duda!" . Penggunaan julukan 'duda' ini mengungkap status DC sebagai seorang duda atau lelaki yang tidak memiliki istri karena sudah bercerai. Pengungkapan kondisi yang sebenarnya ini mengakibatkan mitra tutur kehilangan muka. Penggunaan kata 'duda' di atas sebenarnya dimaksudkan sebagai olok-olok karena tidak ditemukan adanya korelasi antara penyampaian keresahan warga Twitter terhadap DC dengan kata 'duda' sebagai julukan yang ditujukan kepada DC.

Sebaran variasi penggunaan julukan tak pantas, dapat dilihat pada Tabel. Sebagaimana tampak pada Tabel, dari sumber data sebanyak 5 episode siniar YouTube Deddy Corbuzier, ditemukan adanya 5 varian penggunaan julukan tak pantas. Jumlah terbanyak ditempati julukan yang mengungkap keadaan mitra tutur, yaitu sebanyak 10 kata/frasa, sedangkan yang paling sedikit adalah julukan dengan sesuatu yang menjijikkan dengan 2 temuan saja. Fenomena ini disebabkan karena dalam strategi ketidaksantunan positif, penutur menjaga muka positifnya sendiri dengan menyerang muka mitra tutur. Oleh karena itu, tindakan paling dominan yang dilakukan oleh penutur adalah dengan mengungkapkan keadaan atau latar belakang mitra tutur, baik 
dari segi pribadi, sosial, budaya, ataupun yang lainnya. Pengungkapan keadaan semacam ini lebih efektif untuk menyerang muka mitra tutur daripada dengan cara yang lain, karena dengan cara demikian mitra tutur secara langsung akan tertampar dengan kenyataan yang dialaminya.

Tabel: Sebaran Variasi Penggunaan Julukan Tak Pantas

\begin{tabular}{clc}
\hline No & \multicolumn{1}{c}{ Varian Julukan } & Jumlah \\
\hline 1 & Julukan dengan namaanggota tubuh & 7 \\
2 & Julukan dengan perbandingan & 5 \\
3 & Julukan dengan nama hewan & 4 \\
4 & Julukan dengan sesuatu yang menjijikkan & 2 \\
5 & Julukan dengan keadaan mitra tutur & 10 \\
& Total & 28 \\
\hline
\end{tabular}

\section{KESIMPULAN}

Dari penelitian mengenai penggunaan strategi ketidaksantunan dengan julukan tak pantas pada 5 video siniar Deddy Corbuzier di YouTube, ditemukan adanya 5 variasi julukan, masing masing julukan dengan anggota tubuh, julukan dengan perbandingan, julukan dengan nama hewan, julukan dengan sesuatu yang menjijikkan, dan julukan dengan keadaan mitra tutur. Varian yang paling dominan adalah julukan dengan keadaan mitra tutur sedangkan yang paling jarang digunakan adalah julukan dengan sesuatu yang menjijikkan. Penggunaan strategi ketidaksantunan positif dengan julukan tak pantas semacam ini dilakukan oleh penutur dengan tujuan untuk menyelamatkan mukanya sendiri dengan cara menyerang muka mitra tutur.

\section{DAFTAR PUSTAKA}

Culpeper, Jonathan. 1996. "Towards an Anatomy of Impoliteness". Journal of Pragmatics 25: 349-67

Culpeper, Jonathan. 2008. "Reflection on Impoliteness, Relational Work and Power". in D Bousfield \& Locher (eds). M. Impoliteness in Language: Studies on Its Interplay with Power and Practice. Berlin: Mouton de Gruyter

Huang, Yan. 2007. Pragmatics. New York: Oxford University Press

Huang, Yan. 2014. Pragmatics (Second Edition). Oxford: Oxford University Press

Huang, Yan. 2017. The Oxford Handbook of Pragmatics. Oxford: Oxford University Press

Leech, Geoffrey. 1983. The Principles of Pragmatics. New York: Longman Group Ltd.

Levinson, Stephen C. 1983. Pragmatics. Cambridge: Cambridge University Press

Levinson, Stephen C. 1987. Politeness: Some Universals in Language Usage. Cambridge: Cambridge University Press.

Nugroho, Miftah. 2009. "Konteks dalam Kajian Pragmatik" dlm Peneroka Hakikat Bahasa. Yogyakarta: Universitas Sanata Dharma

Rinzat, Muhammad. 2018. "Pudarnya Kaidah Kesantunan pada Masyarakat Indonesia". Jurnal Lingua Franca:Bahasa, Sastra dan Pengajarannya 6 (2)

Shinta, Mara Vini. 2018. "Impoliteness Strategies Used by Supporters dan Detractors of Ahok in Their Online Comments by Gender": English Language and Literature 7: 225-236

Sudaryanto. 1993. Metode dan Aneka Teknik Analisis Bahasa. Yogyakarta: Duta Wacana University Press

Suryanti, Siska. 2019.“Impolite Responses to Donald Trump's Posts on Instagram”. Jurnal Idebahasa 1 (1)

Tasliati. 2019. “Analisis Ketidaksantunan Berbahasa pada Unggahan dalam Grup Daring Jual-Beli di Kota Tanjungpinang”. Jurnal Genta Bahtera 4 (2)

Wigati, Arif. 2017. "Strategi Ketidaksantunan Bertindak Tutur Direktif Anak Sekolah Menengah Pertama dan Implikasinya dalam Pembelajaran Bahasa Indonesia". Jurnal UMS 
Penggunaan Strategi Ketidaksantunan Julukan Tak Pantas dalam Siniar Deddy Corbuzier

Wijayanto, Agus. "Ketidaksantunan Berbahasa: Penggunaan Bahasa Kekerasan di Sinetron Bertema Kehidupan Remaja”. Prosiding Seminar Nasional 115-125

Zaitul, Azma. 2016. "Penggunaan Strategi Ketidaksantunan dalam Kalangan Remaja di Sekolah". Jurnal Linguistik 1: 62-74 